\title{
강우조건에 따른 산악지반의 강도 및 함수특성 Characteristics of Strength and Water Content of Mountain Ground Based on Rainfall Conditions
}

\author{
박근우* . 김남선** . 이종섭*** . 김상엽**** \\ Park, Geun-Woo*, Kim, Namsun**, Lee, Jong-Sub***, and Kim, Sang Yeob***
}

\begin{abstract}
This study aims to evaluate the variations in strength and water content of mountain ground based on rainfall conditions. Field tests using an instrumented dynamic cone penetrometer and time domain reflectometry penetrometer are conducted with rainfall of $60 \mathrm{~mm}$ after 1 and $3 \mathrm{~h}$ and for rainfall of 30 and $90 \mathrm{~mm}$ after $3 \mathrm{~h}$. Results show that the strength and volumetric water content of the ground surface decrease with time. However, the volumetric water content of the ground to depths greater than $300 \mathrm{~mm}$ increases with time. As the rainfall increases to 30,60, and $90 \mathrm{~mm}$, the strength of the ground decreases by 2.4 , 5.4, and 7.5 times, respectively, according to rainfall, and the volumetric water content increases to $7.8,18.5$, and $21.7 \%$, respectively, as compared to the ground before rainfall. This study shows that the strength of the ground rapidly decreases and the volumetric water content of the ground significantly increases under the conditions of $3 \mathrm{~h}$ and $60 \mathrm{~mm}$ of rainfall.
\end{abstract}

Key words : Instrumented Dynamic Cone Penetrometer (IDCP), Mountain Ground, Rainfall, Strength, Time Domain Reflectometry Penetrometer (TDRP)

\section{요 지}

본 연구에서는 강우조건에 따라 산악지반의 강도 및 함수특성 변화를 연구하고자 한다. 산악지반에 대하여 네 구역으로 나누어 각각 강우 전, 강우량 $30 \mathrm{~mm}, 60 \mathrm{~mm}, 90 \mathrm{~mm}$ 조건으로 조성한 후, 강우량 $60 \mathrm{~mm}$ 로 조성된 지반에 대해 1시간, 3 시간 후에 각각 계장화된 동적 콘 관입실험(IDCP test)와 TDR 관입실험(TDRP test)을 수행하여, 심도별 강도 및 체적함수비를 측정하였다. 또한, 강우량 $30 \mathrm{~mm}, 90 \mathrm{~mm}$ 로 조성된 지반에 대해 3시간 후에 동일한 실험을 진행하였다. 동일한 강우량 $(60 \mathrm{~mm})$ 조건으로 시간에 따라 지반의 강도와 체적함수비를 측정하였을 때, 3 시간 후의 강도는 1 시간 후의 강도보다 1.4 배 낮아지는 것으로 나타났으며, 1 시간 후의 체적함수비는 심도 $300 \mathrm{~mm}$ 까지 3 시간 후의 체적함수비보다 높게 나타났지만, 그 이후 심도에서는 반대의 경향을 나타냈다. 또한 강우량이 증가할수록 $(30 \mathrm{~mm}, 60 \mathrm{~mm}, 90 \mathrm{~mm})$, 강우량에 따라 지반의 강도가 2.4배, 5.4 배, 7.5배로 감소하였으며, 체적함수비는 $7.8 \%, 18.5 \%, 21.7 \%$ 증가하였다. 본 연구는 호우주의보(3시간 강우량 $60 \mathrm{~mm})$ 기준 이상에서 지반의 강도가 급격히 감소하고, 지반의 체적함수비가 크게 상승하는 것을 보여준다.

핵심용어 : 계장화된 동적 콘 관입장비, 산악지반, 강우량, 강도, 관입형 TDR

\section{1. 서 론}

건기와 우기가 뚜렷한 우리나라는 국지성 집중호우로
인하여, 매년 하절기(6월 9월)에 산사태가 빈번히 발생한다 (Yune et al., 2010). 우리나라 지리적 특성상 국토면적에서 산지가 $70 \%$ 로 이루어져 있고, 도심지에도 산지가 많이 분포

*정회원, 고려대학교 건축사회환경공학부 박사수료(E-mail: pytann@korea.ac.kr)

Member, Ph.D. Candidate, School of Civil, Environmental and Architectural Engrg., Korea University

**고려대학교 건축사회환경공학부 석사과정(E-mail: skatjs121@naver.com)

Graduate Student, School of Civil, Environmental and Architectural Engrg., Korea University

***정회원, 고려대학교 건축사회환경공학부 교수(E-mail: jongsub@korea.ac.kr)

Member, Professor, School of Civil, Environmental and Architectural Engrg., Korea University

****교신저자, 정회원, 고려대학교 건축사회환경공학부 박사(Tel: +82-2-3290-3838, Fax: +82-2-3290-5999, E-mail: s3778@korea.ac.kr)

Corresponding Author, Member, Ph.D., School of Civil, Environmental and Architectural Engrg., Korea University 
되어 있어 산사태 발생시 막대한 재산손실과 인명피해가 발생한다(Kim et al., 2012). 산림청 2018년도 산사태 보고자 료에 따르면 2008년부터 2017년까지 연평균 450억원의 천 문학적인 피해복구비용이 소모되었으며, 매년 평균 5 명의 인명피해가 발생하였다. 특히 우면산 산사태가 발생하였던 2011 년의 경우 43 명의 인명피해와 1,473 억원의 재산피해가 발생하였다. 이에 따라 정부에서는 산사태 대응방안을 모색 하고, 여러 연구를 통해 산사태발생에 따른 피해를 저감하고 자 하였다.

산사태 피해를 저감하기 위하여 각 지자체에서는 산사태 위험지역을 선정하여 집중관리를 하고 있으며, 방재시설을 설치하고 있다. 산사태 위험지역은 사면의 경사, 산사태 이력 등으로 위험등급을 평가하여 주기적으로 관리하고 있으며, 위험등급이 높은 지역에 대해 예상 피해규모에 따라 방재시설을 설치하였다. 또한 변위, 체적함수비, 강우강도 계측기 설치를 통해 산사태 예 - 경보 시스템을 구축하였다. 국내연구에서는 산사태 발생예측을 위한 연구를 활발히 수행 중이며, 강우강도와 지반조건을 고려하여 예측시뮬레 이터를 개발, 발전시키고 있다. 산사태 예측시뮬레이터의 경우, 강우량과 지반조건에 따라 산사태 발생위험도와 발생 시 피해규모 및 범위를 예측한다(Shin, 2014, 2015; Lee et al., 2015).

국내 산사태 예측을 위한 계측시스템은 대상면적이 넓어 일부 급경사지에 한해 수행중이며(Jeong et al., 2018), 강우 강도를 통해 산사태 발생을 예측하는 예 - 경보 시스템의 경우 약 $60 \%$ 가 산사태 주의보 기준에 미달하는 것으로 나타났다(Kim et al., 2013). 이러한 예측시스템의 정확도 향상을 위해서는 강우조건에 따른 산악지반의 특성변화에 대한 연구가 절실하다. 또한, 국내 산사태 발생 예측 시뮬레 이터에 입력되는 공학정수들(점착력, 내부마찰각 등)은 국 내자료 부족으로 해외연구사례를 도입하는 경우가 많아 정확성이 떨어진다. 산사태 발생 예측 시뮬레이터의 정확성 을 높이기 위해서는 국내 산악지반의 특성에 대한 연구가 절실하다.

본 연구에서는 강우량에 따라 산악지반의 심도별 지반강 도와 체적함수비를 측정하여 산악지반에 대한 강우의 영향 을 연구하고자 한다. 휴대가능한 지반조사장비들을 이용하 여 산악지반의 강도 및 함수특성을 평가하였으며, 강우량 을 $30 \mathrm{~mm}, 60 \mathrm{~mm}, 90 \mathrm{~mm}$ 로 설정하고 대상지반에 해당 강우량조건에 맞게 조성한 후 3 시간 뒤에 원위치 관입실험 을 수행하여 강우량의 영향을 알아보고자 하였으며, 강우 량 $60 \mathrm{~mm}$ 에 대해 1시간 후 측정결과를 통해 강우 후 시간에 따른 지반강도 및 함수특성 변화를 연구하였다. 본 논문은 지반강도 및 함수특성 평가방법에 대해 설명한 후, 강우량 과 측정시기에 따른 현장실험 결과를 도시하고, 이를 통해 강우조건에 따른 지반의 강도 및 함수 특성에 대해 토의하 였다.

\section{2. 지반강도 및 함수특성 평가방법}

산악지반에 대한 지반조사방법은 지리적 특성으로 인하 여 장비의 활용이 제한된다. 경사가 가파르고 고도가 높은 산악지반에는 일반적으로 사용되는 지반조사장비가 접근하 기 힘드며, 주변 식생들로 인하여 직경이 큰 관입장비를 적용하기 힘들다. 이러한 이유로 많은 산사태 위험지역 조사 에는 접근성과 적용성이 떨어지는 대형 지반조사장비 대신 직경이 작고 휴대가능한 소형화된 지반조사 장비가 활용도 가 높다. 따라서 본 연구에서는 휴대가능한 지반강도 평가 장비인 개량된 동적 콘 관입장비인 계장화된 동적 콘 관입기 (Instrumented Dynamic Cone Penetrometer, IDCP)와 지반의 체적함수비 측정이 가능한 관입형 $\mathrm{TDR}$ 장비를 사용하였다.

\subsection{Instrumented Dynamic Cone Penetrometer (IDCP)}

국제적으로 소형화된 지반조사 장비로 사용되는 동적 콘 관입장비(Dynamic Cone Penetrometer, DCP)는 선단부 가 원추형태의 콘이며 두부에 해머 $(8 \mathrm{~kg})$ 를 일정한 낙하고 $(575 \mathrm{~mm})$ 로 동적 타격하여 관입량을 측정하여 지반의 강도를 평가하는 장비이다(Fig. 1). 여기서 측정된 관입량은 동적 콘 관입지수(Dynamic Cone Penetration Index, DCPI) 로 단위는 $\mathrm{mm} / \mathrm{blow}$ 이며, 지반강도를 나타내는 지표로 활용 된다(Meyerhof, 1961; De Mello, 1971; Rahim et al., 2004; Sawangsuriya and Edil, 2005). 동적 콘 관입지수는 경험적 수식을 통해 점착력, 내부마찰각, $\mathrm{CBR}$ 등과 같은 공학정수를 추산하는데 활용된다(Abu-Farsakh et al., 2004; Kim and Lee, 2019).

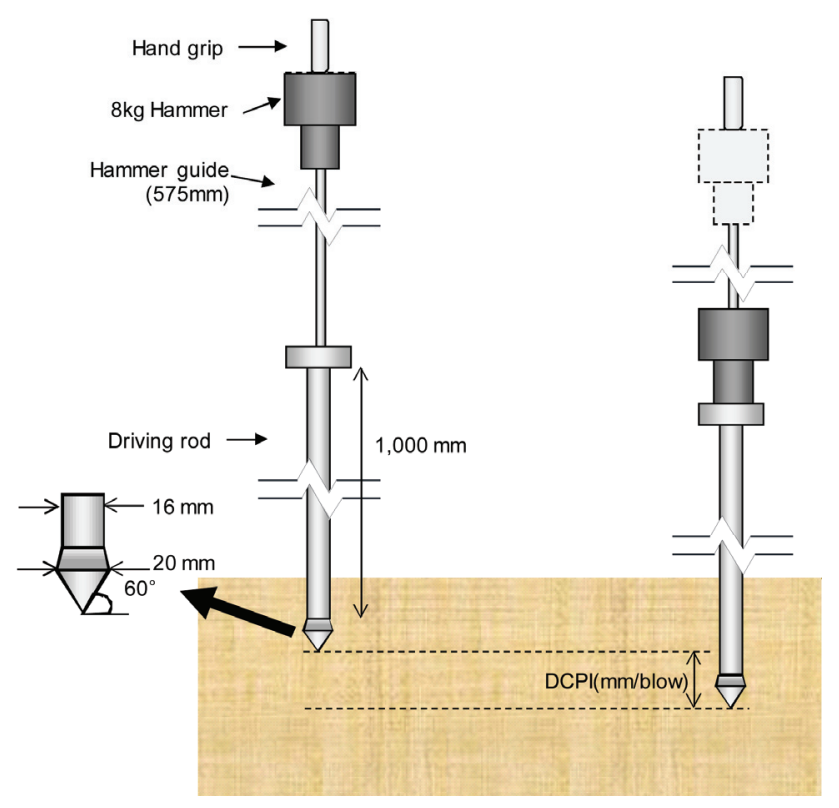

Fig. 1. Dynamic Cone Penetrometer and Measurement of Dynamic Cone Penetration Index (DCPI) 
동적 콘 관입장비는 좋은 휴대성과 편리성으로 널리 사용 되지만, 에너지 손실로 인하여 실험결과의 정확도가 떨어진 다. 해머와 해머가이드 간에 마찰로 인한 에너지 손실과 에너지가 두부에서 선단부로 전달될 때 발생하는 에너지 손실로 선단부에서의 에너지와 위치에너지 $(45 \mathrm{~N} \cdot \mathrm{m})$ 간의 차이가 발생한다(Sun et al., 2011). 계장화된 동적 콘 관입장 비는 이러한 단점을 극복하기 위하여 개량된 장비로, 두부 에너지 모듈과 선단부 에너지 모듈을 통해 실제 콘에 가해진 에너지를 계산할 수 있다(Byun and Lee, 2013; Byun et al., 2014; Kim et al., 2016; Kim and Lee, 2019; Kim et al., 2019). 에너지측정을 위하여 에너지 모듈에는 변형률계 와 가속도계가 설치되어 있으며, 변형률계와 가속도계로부 터 시간에 따른 힘과 속도를 측정할 수 있다(Fig. 2). 변형률계 는 편심을 보정하고 온도를 보상할 수 있도록 휘트스톤 풀브리지(Wheatstone full-bridge) 회로로 구성하였으며, 단 면에서의 입자속도를 측정하기 위해 동일한 위치에 가속도 계를 설치하였다. 이에 따라, 각 센서로부터 획득한 힘과 속도를 적분하여 (F-V method) 해당 위치의 실제 전달된 에너지를 산정하였다.

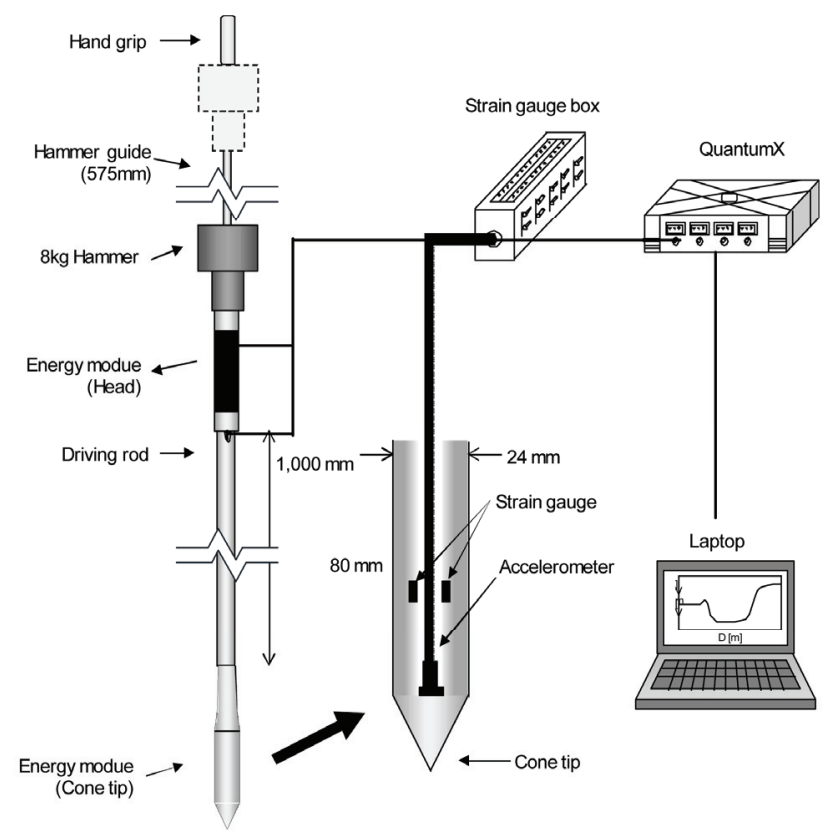

Fig. 2. Schematic Drawing of Instrumented Dynamic Cone Penetrometer

\subsection{Time Domain Reflectometry Penetrometer (TDRP)}

불포화토 지반의 체적함수비를 측정하기 위하여 훍의 유전상수을 측정할 수 있는 TDR 기법을 사용한다(Topp et al., 1980). TDR 기법은 전기적 불연속성을 나타내는 유전체 에 대하여 전자기적 신호를 송신하고, 반사파를 수신하여 유전상수를 산정한다. 각기 다른 유전체 마다 다른 유전상수
값을 나타내며, 대표적으로 공기의 유전상수는 1 , 물의 유전 상수는 81 , 건조토의 유전상수는 3 8 로 나타난다. 물과 휽이 공존하는 불포화토 같은 경우 함수비에 따라 유전상수가 민감하게 변화한다. 이러한 특성으로부터 많은 연구자들은 $\mathrm{TDR}$ 프로브를 이용하여 훍의 체적함수비를 측정하였다 (O'Connor and Dowding, 1999).

$\mathrm{TDRP}$ 는 선단부에 $8 \mathrm{~cm}$ 전극 3 개가 설치되어 있는 $\mathrm{TDR}$ 프로브가 있으며, TDR 프로브와 롯드를 채결하여 해머와 해머가이드를 통해 동적관입을 할 수 있도록 설계되었다 (Fig. 3). 타겟 심도에 대하여 reflectometry를 통해 측정된 $\mathrm{TDR}$ 파형을 획득하여 유전상수를 산정할 수 있으며, 산정된 유전상수는 실내실험을 통해 도출된 유전상수-체적함수비 관계식을 통해 체적함수비로 환산할 수 있다.

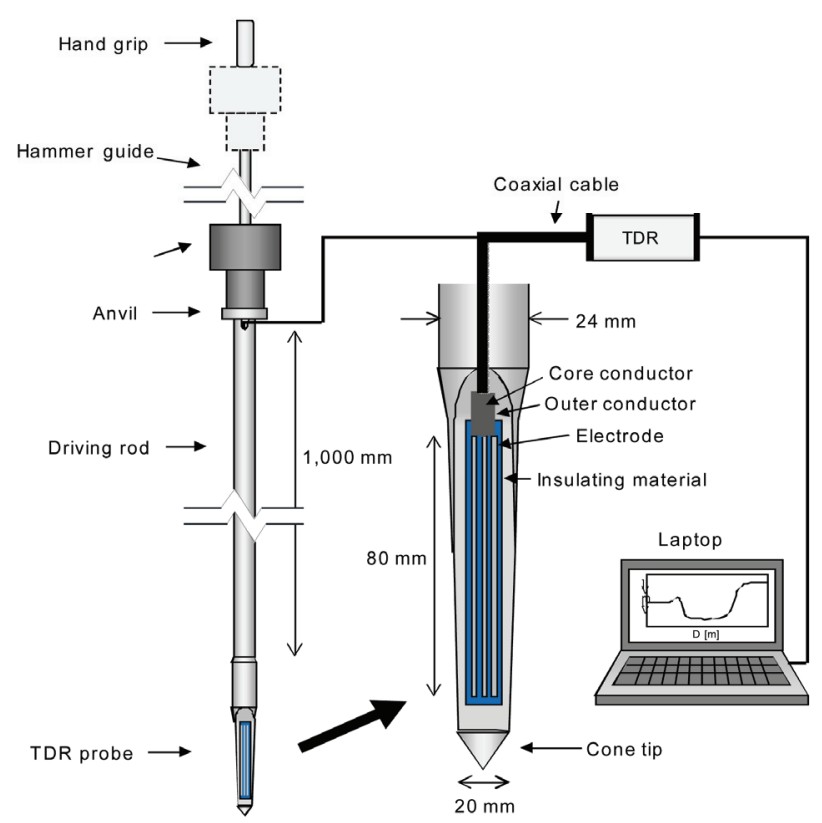

Fig. 3. Schematic Drawing of Time Domain Reflectometry Penetrometer

본 연구에서 유전상수-체적함수비 관계식을 도출하기 위 하여 직경 $30 \mathrm{~cm}$, 높이 $30 \mathrm{~cm}$ 의 원통형 토조에서 실험을 진행하였다(Fig. 4). 시료는 현장실험이 진행된 서울시 성북 구 개운산 부근에서 채취하였으며, 각각 $0 \%, 10 \%, 20 \%$, $30 \%, 40 \%$ 로 체적함수비를 조성하였으며, 조성된 시료에 대하여 Fig. 5(a) 같은 TDR 파형을 획득하였다. 획득된 파형 들에 대하여 획득한 유전상수 $\left(\mathrm{K}_{\mathrm{a}}\right)$ 와 체적함수비 $(\Theta)$ 의 관계 를 Fig. 5(b)에 나타내었다. Fig. 5(b)에서 나타난 유전상수 $\left(\mathrm{K}_{\mathrm{a}}\right)$ 와 체적함수비 $(\Theta)$ 의 관계를 Eq. (1)과 같이 3차 다항식으 로 나타내었다.

$$
\Theta=0.1744 \mathrm{~K}_{\mathrm{a}}{ }^{3}-5.5646 \mathrm{~K}_{\mathrm{a}}{ }^{2}+58.5 \mathrm{~K}_{\mathrm{a}}-175.28
$$




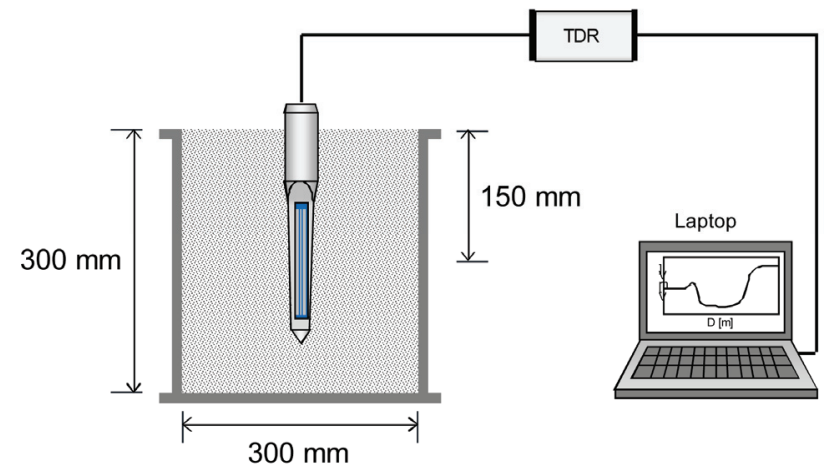

Fig. 4. Calibration of Time Domain Reflectometry Penetrometer

유전상수와 체적함수비 관계식은 프로브 형태에 따라 다르게 나타나는데, Topp et al. (1980)은 전극을 훍과 단독으

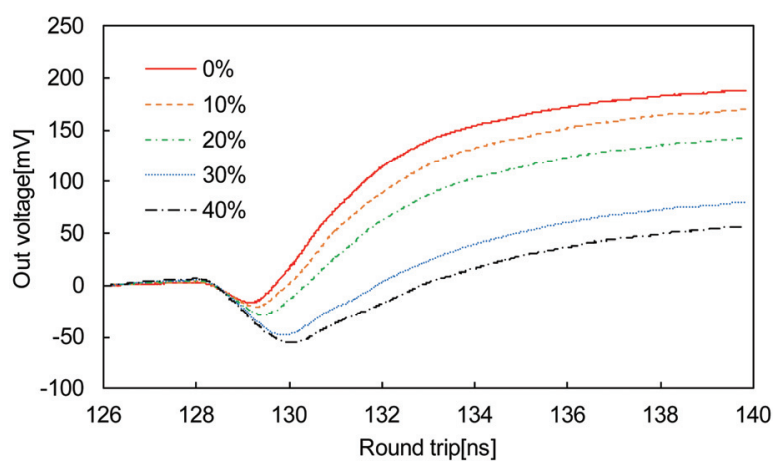

(a) TDR wave form
로 접촉시켜 유전상수를 측정함으로써 관계식을 도출하였 지만, TDRP는 모듈형식으로 전극이 $\mathrm{MC}$ 나일론 안에 설치되 어있어, 전극뿐 아니라 전극주변의 물질에 영향을 받아 계수 가 다르게 나타난다(Hong et al., 2015; Lee et al., 2018).

\section{3. 현장실험 수행 및 결과}

\section{1 현장실험}

강우에 따른 지반강도와 함수특성 변화를 연구하기 위하 여 서울 성북구 개운산 인근의 평지에서 실험을 수행하였다. 시험공은 총 10 공으로 IDCP 5 공, TDRP 5 공으로 boundary effect를 고려하기 위하여 각 공의 간격을 세로로 $30 \mathrm{~cm}$ 가로로 $40 \mathrm{~cm}$ 로 설정하였으며, 각 시험공의 위치는 Fig. 6 과 같다. 먼저, BH-1, 2는 건조한 상태에서 실험을 수행하였으며,

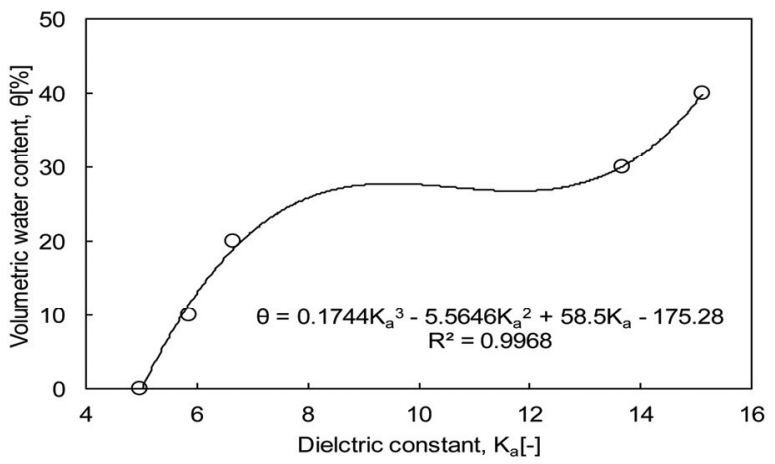

(b) Correlation between dielectric constant and volumetric water content

Fig. 5. Result of TDR Calibration Test

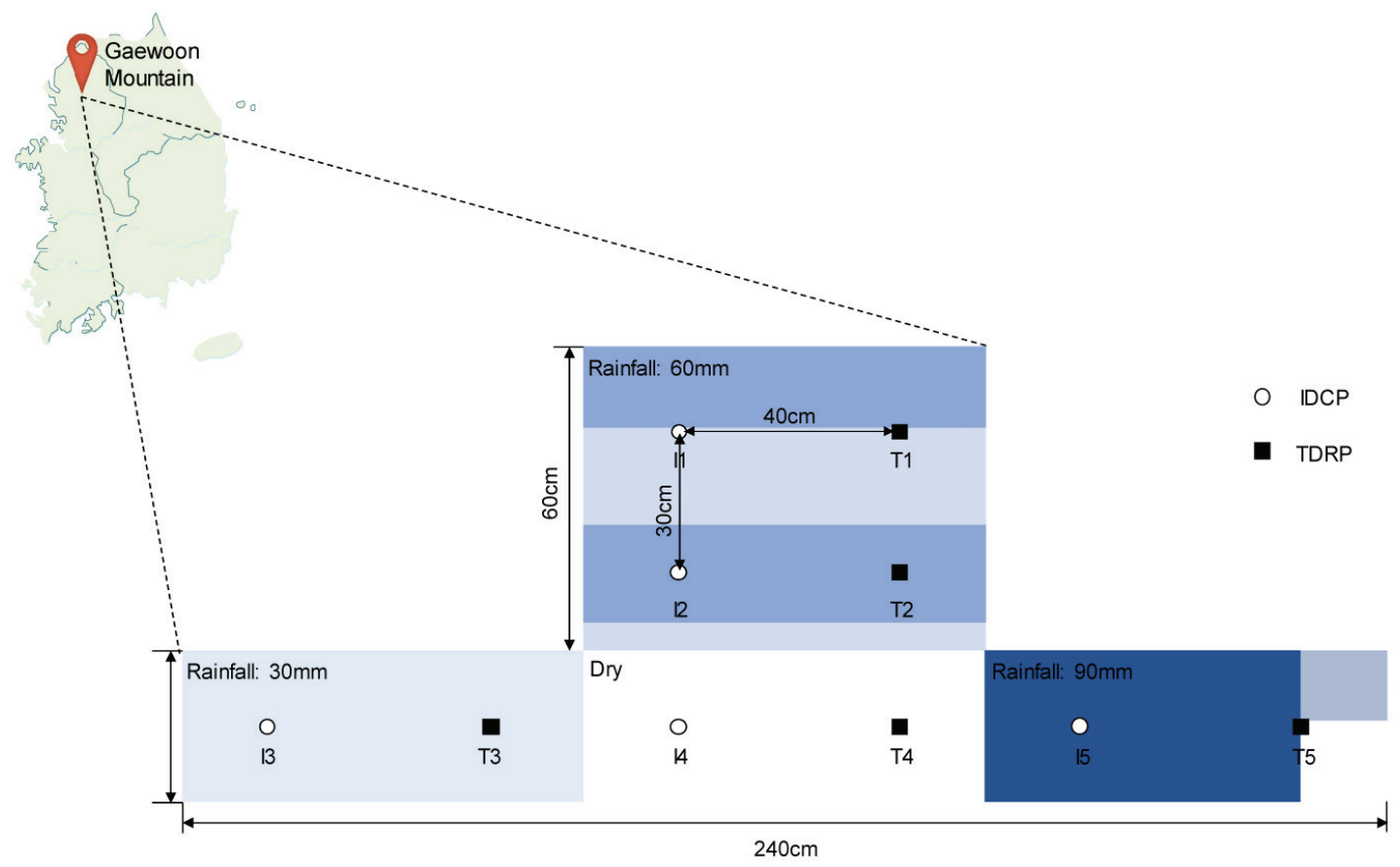

Fig. 6. Location of Test Site and Borehole 
$\mathrm{BH}-3,4$ 는 강우 $60 \mathrm{~mm}$ 에 대하여 1 시간 경과 후에 측정하였으 며, $\mathrm{BH}-7,8$ 은 같은 강우에 대해 3시간 경과 후에 측정하였다. $\mathrm{BH}-5,6$ 과 $\mathrm{BH}-9,10$ 은 각각 강우 $30 \mathrm{~mm}$ 와 $90 \mathrm{~mm}$ 에 대해 3 시간 경과 후에 측정한 시험공이다. $\mathrm{IDCP}$ 의 경우 각 1 타마 다 두부와 선단부의 에너지를 측정하였으며, 관입깊이를 산정하였다. 또한 TDRP는 심도별 $10 \mathrm{~cm}$ 단위로 TDR 파형을 획득하였으며, 두 실험 모두 최대 $1 \mathrm{~m}$ 심도를 대상으로 실험을 진행하였다.

\section{$3.2 \mathrm{IDCP}$ 결과}

현장에서 강우조건에 따라 계장화된 동적 콘 관입실험을 진행하였으며, 관입량을 측정한 후, 두부와 선단부의 에너지 를 산정하였다. 두부와 선단부에 설치된 가속도계와 스트레 인 게이지에서 가속도와 힘을 측정하고(Fig. 7(a)), F-V 적분
법을 통해 에너지를 산정하였다(Fig. 7(b)). 측정된 관입량에 대하여 산정된 두부와 선단부 에너지의 평균과 위치에너지 를 통해 에너지보정을 하였다.

에너지보정을 통해 산정된 DCPI를 심도에 따라 나타내었 다(Fig. 8). 각각의 지반상태에 따라 최대 관입심도는 500 $\mathrm{mm} \sim 700 \mathrm{~mm}$ 로 나타났다. 강우 전 건조한 상태의 지반(I4)의 경우, Fig. 8(d)에 도시된 것과 같이DCPI가 심도 $0 \mathrm{~mm}$ $300 \mathrm{~mm}$ 에서는 약 $20 \mathrm{~mm} / \mathrm{blow}$ 로 나타났으며, 심도 $400 \mathrm{~mm}$ $600 \mathrm{~mm}$ 에서는 약 $30 \mathrm{~mm} / \mathrm{blow}$, 심도 $650 \mathrm{~mm}$ 이하에서는 $5 \mathrm{~mm} / \mathrm{blow}$ 로 나타났다. $60 \mathrm{~mm}$ 강우 후 1시간 후에(I1) DCPI를 측정하였을 경우, Fig. 8(a)와 같이 심도 $100 \mathrm{~mm}$ 까지는 강우 전 보다 $\mathrm{DCPI}$ 가 약 2배 증가하였다. $30 \mathrm{~mm}$, $60 \mathrm{~mm}, 90 \mathrm{~mm}$ 강우 후 3 시간 후에 측정할 경우(I2, I3, I5), Figs. 8(b), (c), (e)와 같이 심도 $200 \mathrm{~mm}$ 까지 DCPI가 최대
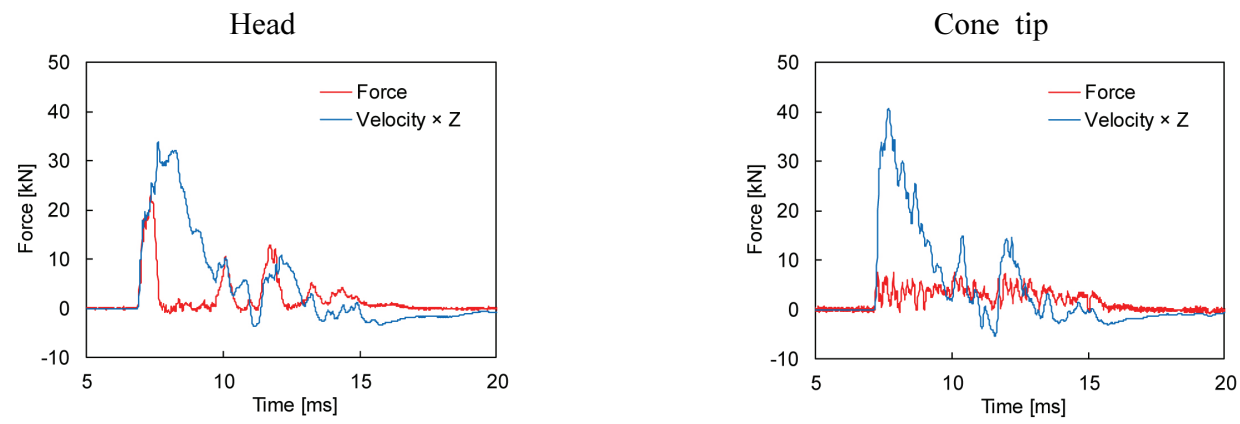

(a) Force-time waveform
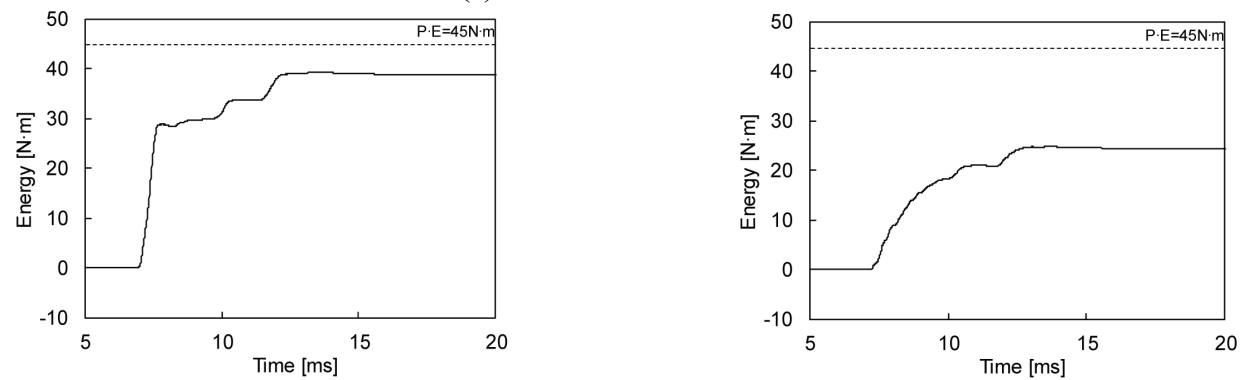

(b) Energy-time waveform

Fig. 7. Typical Force and Transferred Energy Signature: (a) force-time waveform; (b) energy-time waveform

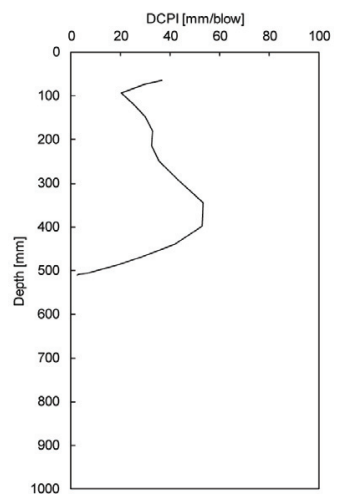

(a) I1

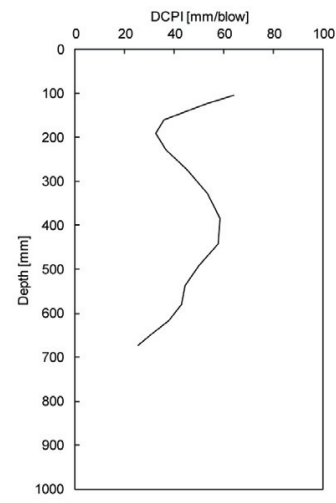

(b) I2

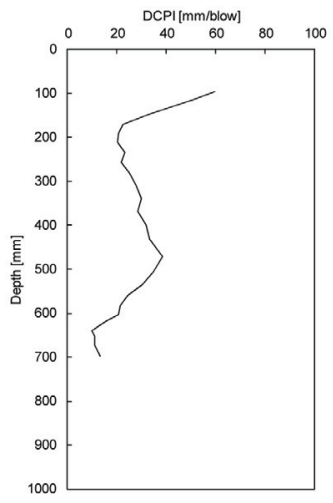

(c) $\mathrm{I} 3$

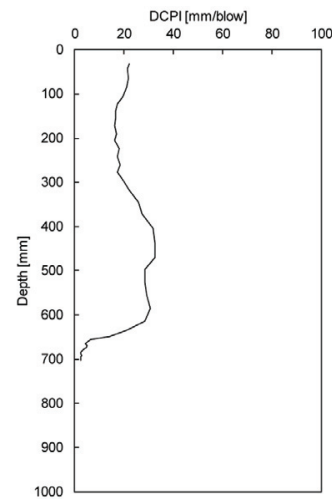

(d) I4

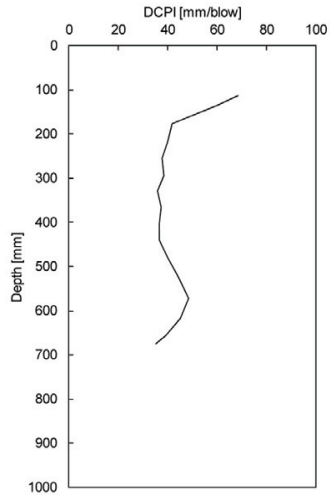

(e) I5

Fig. 8. Result of IDCP Test 
3 배이상 증가하였으며, 강우량이 많을수록 초반 DCPI가 높은 값을 나타내었다. 강우량을 $60 \mathrm{~mm}$ 조건으로 조성한 지반(I1, I2)의 경우, Figs. 8(a)와 (b)에 도시된 것과 같이 다른 지반과 다르게 심도 $200 \sim 500 \mathrm{~mm}$ 에서 느슨한 지반이 나타났으며, 각각 $500 \mathrm{~mm}$ 와 $700 \mathrm{~mm}$ 에서 암반이 나타났다.

\subsection{TDRP 결과}

$\mathrm{IDCP}$ 와 동일한 강우조건에 대하여 $40 \mathrm{~cm}$ 떨어진 거리에 서 TDRP 실험을 진행하였으며, $10 \mathrm{~cm}$ 간격으로 TDR 파형을 획득하였다(Fig. 9). 획득된 TDR 파형에서 유전상수를 산정 하고, 유전상수-체적함수비 관계식에 따라 심도별 체적함수 비를 산정하였다(Fig. 10). 각 지반에 따라 최대심도 $60 \mathrm{~cm}$ $\sim 70 \mathrm{~cm}$ 까지 측정하였으며, 강우 전 건조한 상태의 지반(T4) 은 Fig. 10(d)와 같이 대체적으로 체적함수비가 약 $15 \%$ 인 것으로 나타났다. 강우 $30 \mathrm{~mm}, 60 \mathrm{~mm}, 90 \mathrm{~mm}$ 의 조건으로 조성된 지반(T2, T3, T4, T5)에서 측정된 체적함수비는 Fig. 10 (b) (e)에서와 같이 모두 $20 \%$ 이상으로 나타났으며, 강우 량과 측정시기에 따라 심도별 체적함수비가 다르게 나타났 다. 강우량 $60 \mathrm{~mm}, 1$ 시간 후 측정(T1)하였을 때, 심도 500 $\mathrm{mm}$ 까지 체적함수비가 $33 \% \sim 38 \%$ 로 산정되었으며(Fig. $10(\mathrm{a})$ ), 같은 강우량에 3 시간 후 측정(T2)한 결과는 같은

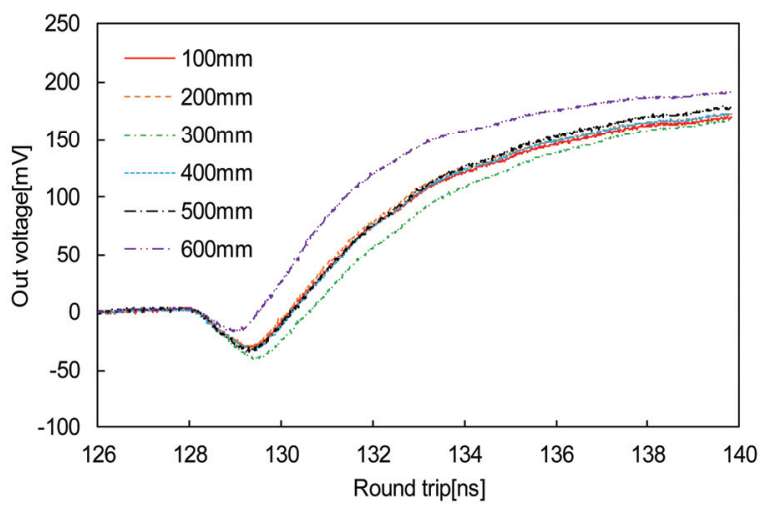

Fig. 9. Measured TDR Waveform of T1 (60 mm, 1hr)
심도에 대해 체적함수비가 $29 \% \sim 35 \%$ 로 산정되어, 심도별 로 체적함수비가 감소한 것으로 나타났다(Fig. 10(b)). 강우 량 $30 \mathrm{~mm}$ 조건에서 3 시간 후에 측정(T3)한 결과에서는 체적함수비가 $19 \% \sim 27 \%$ 로 산정되었으며(Fig. $10(\mathrm{c})$ ), 강우 량 $90 \mathrm{~mm}, 3$ 시간 후 측정(T5)의 경우, 체적함수비가 $31 \%$ 39\%로 나타났다(Fig. 10(e)).

\section{4. 분석 및 토의}

현장실험 결과를 토대로 강우조건에 따른 지반 강도 및 함수특성 변화에 대해 논의하고자 한다.

\section{1 강도특성 변화}

동일한 강우량 $(60 \mathrm{~mm})$ 에 대해 다른 시간대에 측정한 결과를 Fig. 11(a)에 나타내었다(I1, I2, I4). Fig. 11(a)와 같이 3시간 후의 DCPI는 1시간 후의 DCPI보다 조금 높게 산정되었다. 심도 $450 \mathrm{~mm}$ 까지 강우 전 건조한 상태에서의 DCPI는 $16.3 \mathrm{~mm} / \mathrm{blow}$ 로 나타났으며, 강우량 $60 \mathrm{~mm}$ 에 대해 1 시간 후에 측정한 DCPI는 $32.8 \mathrm{~mm} / \mathrm{blow}, 3$ 시간 후에 측정한 $\mathrm{DCPI}$ 는 $44.5 \mathrm{~mm} / \mathrm{blow}$ 로 나타났다. 강우 전과 비교하여 지반 의 강도가 각각 2 배, 2.7 배 낮아진 것으로 나타났다. 심도 $200 \mathrm{~mm}, 300 \mathrm{~mm}, 400 \mathrm{~mm}$ 에 대하여 시간에 따른 DCPI 변화를 Fig. 11(b)에 나타내었다. 세 심도에서 모두 시간에 따라 DCPI 값이 증가하는 경향이 나타났으며, 강우 후에는 강우 전보다 약 2 배 정도 지반의 강도가 낮아졌다.

Fig. 12(a)는 강우량에 따른 DCPI로 강우량에 따라 DCPI 가 전반적으로 증가하는 것으로 나타났다. 심도 $200 \mathrm{~mm}$ $\sim 500 \mathrm{~mm}$ 에서는 BH-5,7에서의 DCPI값이 급격히 증가하는 데 이는 강우량 $60 \mathrm{~mm}$ 로 조성한 지반이 다른 지반과 달리 해당심도에서 매우 느슨한 지반이 형성되어 있어, 다른 강우 조건과의 비교에서 제외하였다. 해당심도를 제외하고 심도 $100 \mathrm{~mm}, 150 \mathrm{~mm}, 200 \mathrm{~mm}, 675 \mathrm{~mm}$ 에서 강우량에 따른 DCPI 결과를 Fig. 12(b)에 나타내었다. 심도 $200 \mathrm{~mm}$ 까지 $\mathrm{DCPI}$ 를 비교하면, 강우 전은 $18.7 \mathrm{~mm} / \mathrm{blow}$, 강우량 $30 \mathrm{~mm}$,

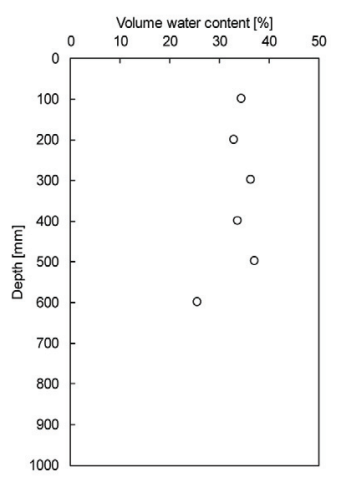

(a) $\mathrm{T} 1$

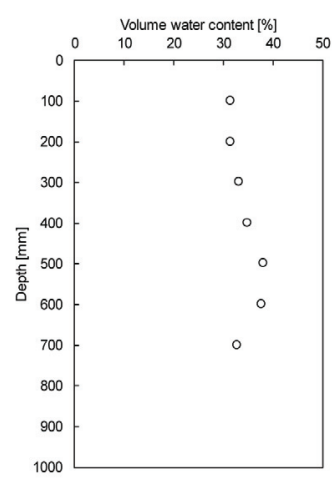

(b) $\mathrm{T} 2$

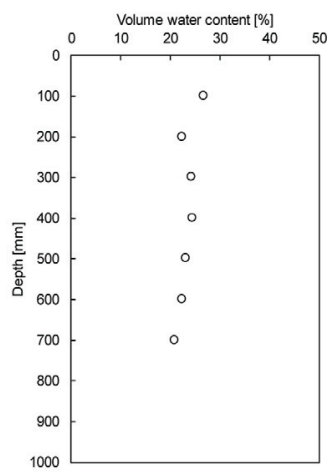

(c) $\mathrm{T} 3$

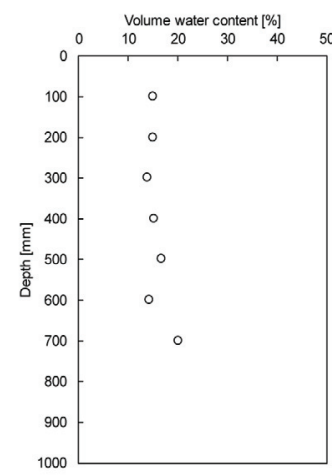

(d) $\mathrm{T} 4$

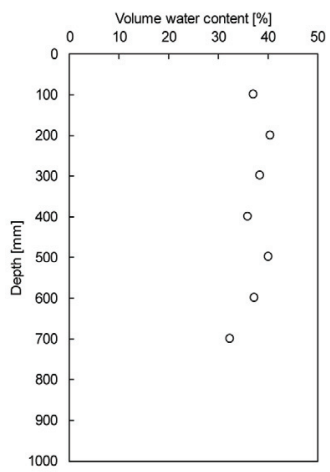

(e) $\mathrm{T} 5$

Fig. 10. Result of TDRP Test 


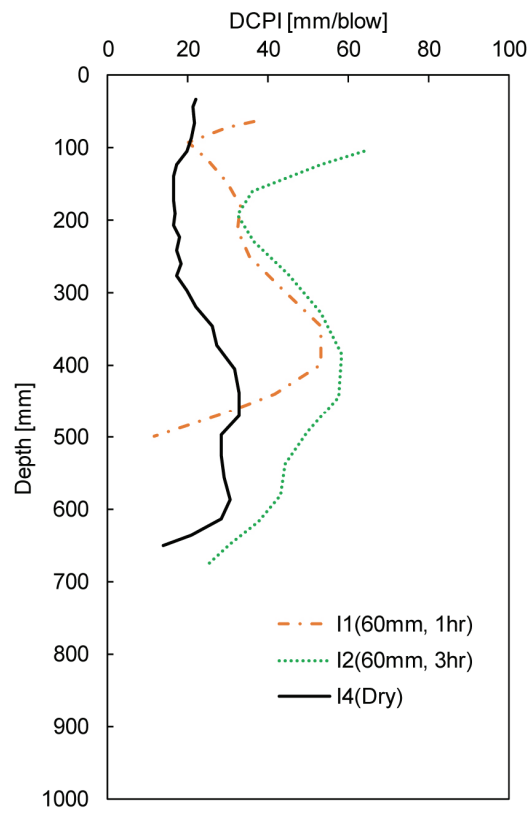

(a) I1, I2 and I4

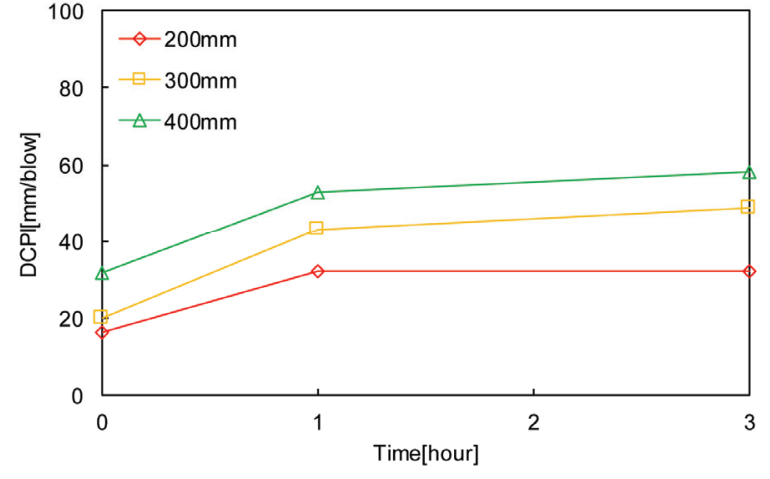

(b) DCPI at $200 \mathrm{~mm}, 300 \mathrm{~mm}$ and $400 \mathrm{~mm}$

Fig. 11. Result of IDCP Test According to Time

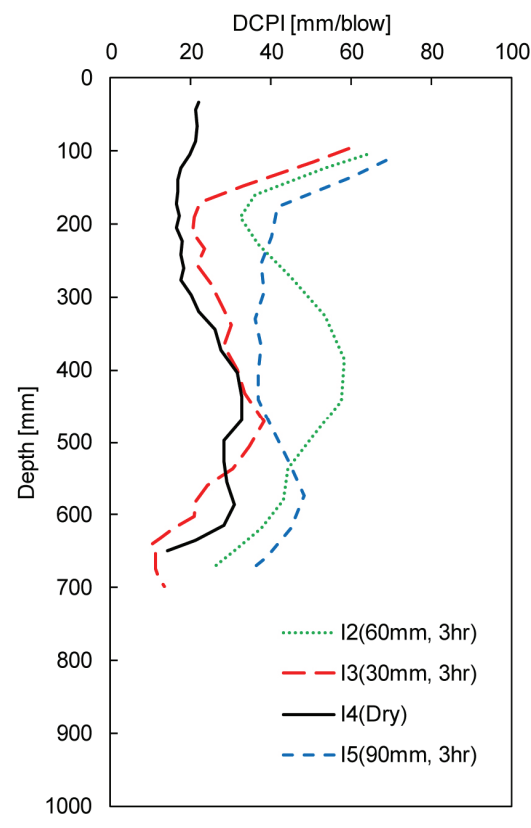

(a) I2, I3, I4 and I5

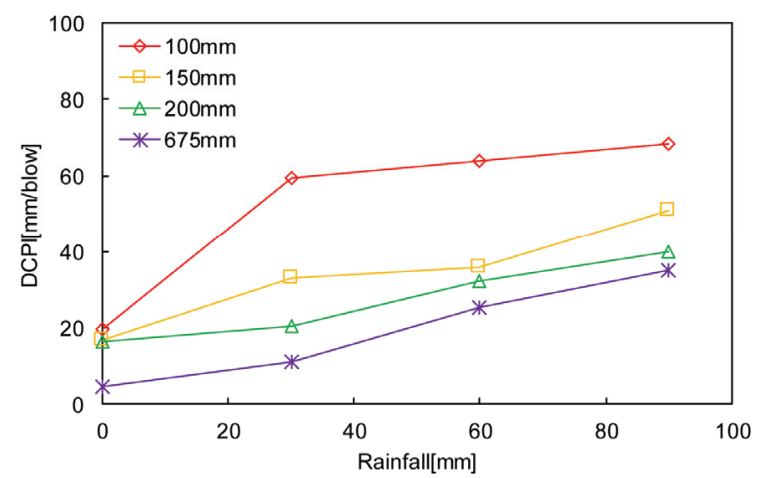

(b) DCPI at $100 \mathrm{~mm}, 150 \mathrm{~mm}, 200 \mathrm{~mm}$ and $675 \mathrm{~mm}$

Fig. 12. Result of IDCP Test According to Rainfall

$60 \mathrm{~mm}, 90 \mathrm{~mm}$ 에 따라 각각 $37.2 \mathrm{~mm} / \mathrm{blow}, 46.4 \mathrm{~mm} / \mathrm{blow}$, $52.5 \mathrm{~mm} / \mathrm{blow}$ 로 강우 전에 비해 각각 2배, 2.5배, 2.8배 DCPI가 증가한 것으로 나타났으며, 측정 최대 심도인 $675 \mathrm{~mm}$ 에서는 $\mathrm{DCPI}$ 가 2.4배, 5.4배, 7.5배 증가하였다. 심도 $675 \mathrm{~mm}$ 에서의 $\mathrm{DCPI}$ 는 강우량에 따라 선형적으로 증가함을 알 수 있다.

$\mathrm{DCPI}$ 는 지반의 강도를 평가하는 지표로 기존 많은 연구들 은 점착력, 내부마찰각 등과 같은 공학정수와의 관계식을
도출하였다. Mohammadi et al. (2008)은 실내실험을 통해 $\mathrm{DCPI}$ 와 유효마찰각( $\phi$ ') 간의 관계식을 도출하였으며, DCPI 와 유효마찰각( $\left.\phi^{\prime}\right)$ 간의 관계식은 다음과 같다.

$$
\phi^{\prime}=52.16 /(\mathrm{DCPI})^{0.13}
$$

Eq. (2)에 따라 Figs. 11(a)와 12(a)의 DCPI를 유효마찰각 
으로 변환하여 각 실험공에 대한 심도별 유효마찰각을 Fig. 13 에 도시하였다. Table 1은 DCPI와 유효마찰각의 값에 따라 지반의 강도를 5 단계로 나타낸 것으로(Mohammadi et al., 2008), 매우 느슨함, 느슨함, 보통, 밀함, 매우 밀함으로 구분하였다. 강우량 $60 \mathrm{~mm}$ 조건에서 강우 전 · 후 시간에 따른 심도별 유효마찰각을 Fig. 13(a)에 나타내었으며, 강우 량에 따른 심도별 유효마찰각을 Fig. 13(b)에 나타내었다. Fig. 13에 나타난 유효마찰각을 전 심도에 대하여 평균 유효 마찰각을 산정하고, 산정된 평균 유효마찰각을 Table 1의 기준과 비교하여 지반의 강도를 판단하였다. 강우 전에는 평균 유효마찰각이 $35^{\circ}$ 로 나타나 보통으로 구분할 수 있다 (I4). $60 \mathrm{~mm}$ 강우 후 1 시간 후에 측정된 평균 유효마찰각은 $33.2^{\circ}$ 로 느슨함으로 나타났으며(I1), 3시간 후에는 평균 유효 마찰각이 $31.9^{\circ}$ 로 감소하였고, 지반의 강도는 느슨한 것으로 판단되었다(I2). 강우량 $30 \mathrm{~mm}$ 조건에서 3시간 후에 산정된 지반의 평균 유효마찰각은 $34.9^{\circ}$ 로 나타나 강우 전과 같이 보통으로 나타낼 수 있다(T3). 강우량 $90 \mathrm{~mm}$ 조건에서 3시간
후에 측정된 지반의 평균 유효 마찰각은 $32.0^{\circ}$ 로 느슨함으로 구분할 수 있다. 강우량 $60 \mathrm{~mm}$ 를 기준으로 지반의 상태가 보통에서 느슨함으로 변화하였다.

\section{2 함수특성 변화}

지반의 체적함수비는 강우량 조건에 따라 민감하게 변하 였으며, Fig. 14(a)는 강우량 $60 \mathrm{~mm}$ 조건에서 강우 전 · 후 심도별 체적함수비이다. 강우 전에는 심도 $700 \mathrm{~mm}$ 까지 평균 체적함수비가 $15.8 \%$ 인 것으로 나타났다(T4). $60 \mathrm{~mm}$ 강우 후 1 시간 뒤에 측정한 체적함수비는 심도 $500 \mathrm{~mm}$ 까지 $30 \%$ 이상으로 측정되었으며(T1), 3 시간 후에는 측정 최대심도인 $700 \mathrm{~mm}$ 까지 $30 \%$ 이상으로 측정되었다(T2). 강우 후 1 시간과 3 시간에서의 체적함수비 변화를 비교하면 심도 $300 \mathrm{~mm}$ 까지는 강우 후 1시간에서 체적함수비가 높았 으며, 그 이하 심도에서는 강우 후 3 시간 때에 더 높은 체적함 수비가 측정되었다(Fig. 14(b)). 이는 지반 내 함수의 이동으 로 Fig. 14(b)와 같은 경향이 나타난 것으로 보인다.

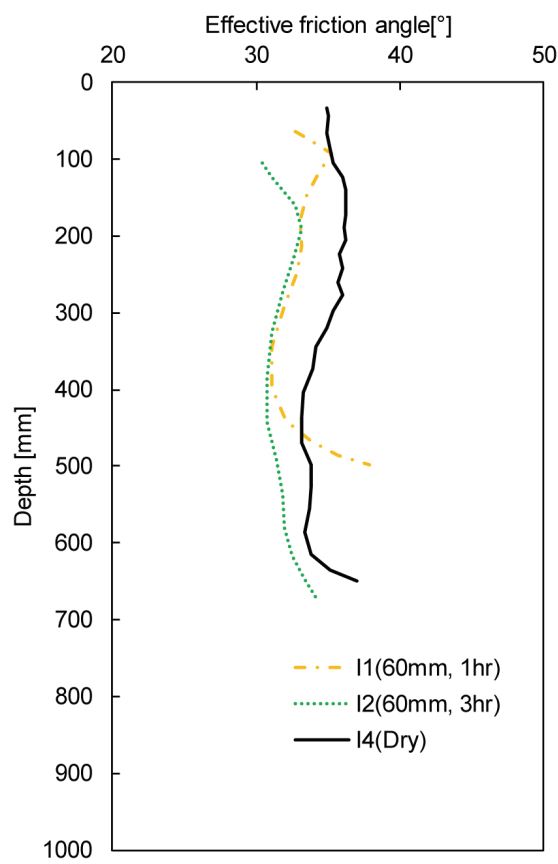

(a) According to time

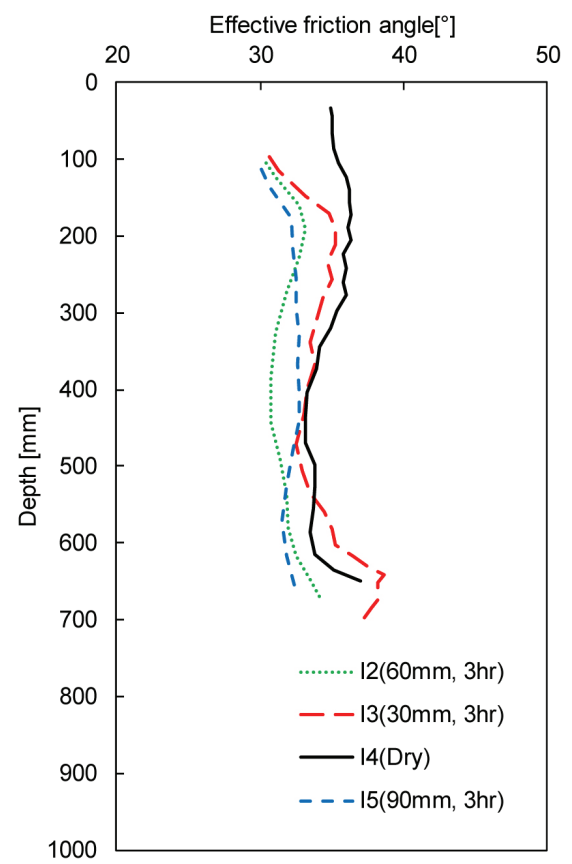

(b) According to rainfall

Fig. 13. Effective Friction Angle for Depth

Table 1. Soil Classification According to Effective Friction Angle and DCPI (Mohammadi et al., 2008)

\begin{tabular}{c|c|c}
\hline DCPI $[\mathrm{mm} / \mathrm{blow}]$ & Effective friction angle ${ }^{\circ}{ }^{]}$ & Description \\
\hline$>45$ & $<30$ & Very loose \\
\hline $25 \sim 45$ & $30 \sim 34$ & Loose \\
\hline $15 \sim 25$ & $34 \sim 36$ & Medium \\
\hline $5 \sim 15$ & $36 \sim 42$ & Dense \\
\hline$<5$ & $<42$ & Very dense \\
\hline
\end{tabular}




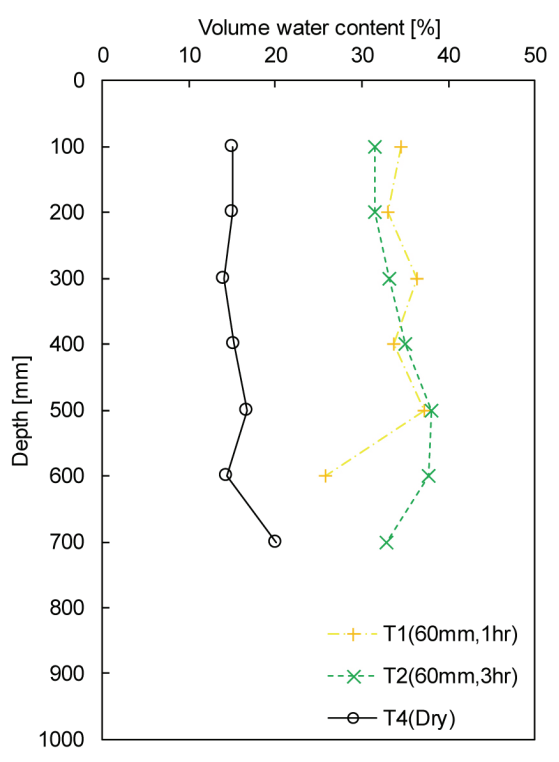

(a) $\mathrm{T} 1, \mathrm{~T} 2$ and $\mathrm{T} 4$

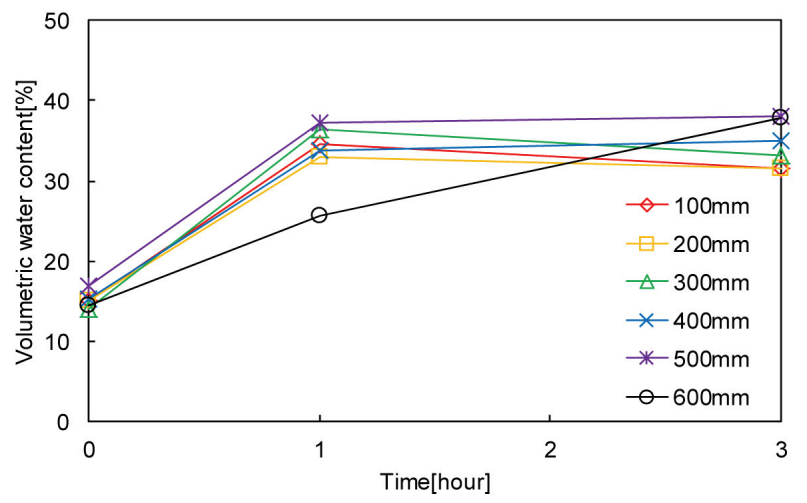

(b) Volumetric water content at $100 \mathrm{~mm}, 200 \mathrm{~mm}, 300 \mathrm{~mm}$, $400 \mathrm{~mm}, 500 \mathrm{~mm}$ and $600 \mathrm{~mm}$

Fig. 14. Result of TDRP Test According to Time

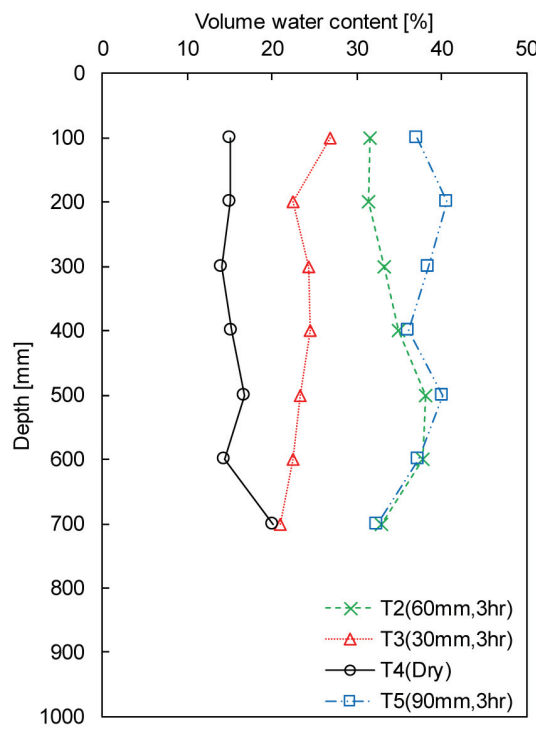

(a) T2, T3, T4 and $\mathrm{T} 5$

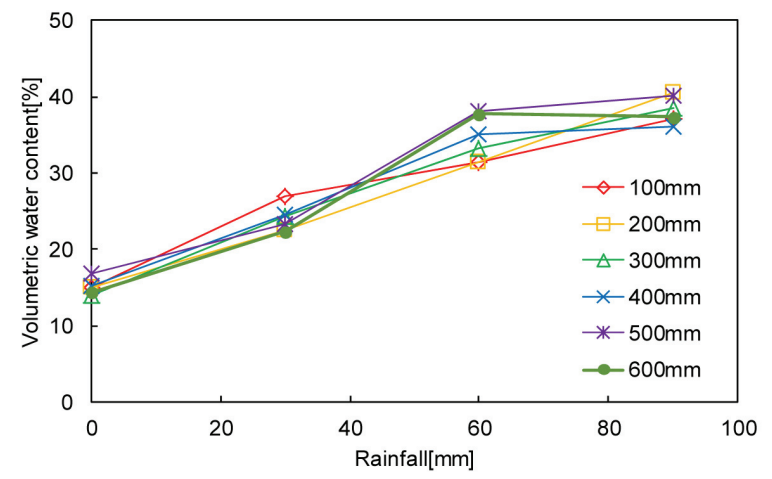

(b) Volumetric water content at $100 \mathrm{~mm}, 200 \mathrm{~mm}, 300 \mathrm{~mm}$, $400 \mathrm{~mm}, 500 \mathrm{~mm}$ and $600 \mathrm{~mm}$

Fig. 15. Result of TDRP Test According to Rainfall

강우량에 따른 경향을 보면, Fig. 15(a)와 같이 강우량(30 $\mathrm{mm}, 60 \mathrm{~mm}, 90 \mathrm{~mm}$ )에 따라 3시간 후에 측정된 체적함수비 는 각각 $23.6 \%, 34.3 \%, 37.5 \%$ 로 측정되어, 강우 전 체적함수 비(15.8\%)와 비교하여 각각 $7.8 \%, 18.5 \%, 21.7 \%$ 증가하는 것으로 나타났다. 강우량 $30 \mathrm{~mm}$ 의 결과와 강우량 $60 \mathrm{~mm}$, $90 \mathrm{~mm}$ 의 결과를 비교하면, 강우 후 체적함수비 증가량이 2.5 배 정도 상승하는 것으로 나타나 강우량 $60 \mathrm{~mm}$ 이상의 조건에서 지반의 체적함수비가 급격히 증가함을 알 수 있다. 또한, 심도 $100 \mathrm{~mm}$ 부터 심도 $600 \mathrm{~mm}$ 까지 강우량에 따른
체적함수비를 Fig. 15(b)에 나타내었으며, 심도 $100 \mathrm{~mm}$ $\sim 300 \mathrm{~mm}$ 보다 심도 $400 \mathrm{~mm} \sim 600 \mathrm{~mm}$ 에서 강우량 30 $\mathrm{mm} \sim 60 \mathrm{~mm}$ 간의 체적함수비 차이가 급격히 증가하는 것으로 나타났다.

\section{5. 요약 및 결론}

본 연구에서는 강우조건에 따른 지반의 강도 및 함수특성 변화를 연구하고자 계량화된 동적 콘 관입장비(IDCP)와 
관입형 TDR 장비(TDRP)를 산악지반에 적용하였다. 지반의 강도를 평가하기 위해 동적 타격을 통해 콘의 관입량을 측정하고, 콘의 두부와 선단부에 전달된 에너지측정으로 에너지보정을 하여 심도별 DCPI를 산정하였다. 산정된 $\mathrm{DCPI}$ 를 유효마찰각로 변환하여 지반의 강도를 판단하였다. 관입형 TDR 장비는 실내실험을 통해 유전상수와 체적함수 비의 관계식을 도출하였고, 도출된 관계식을 통해 현장실험 에서 측정된 TDR파형에 대해 심도별 체적함수비를 산정하 였다.

현장실험은 강우 전, 강우강도 $30 \mathrm{~mm} / 3 \mathrm{hr}, 60 \mathrm{~mm} / 1 \mathrm{hr}$, $60 \mathrm{~mm} / 3 \mathrm{hr}, 90 \mathrm{~mm} / 3 \mathrm{hr}$ 로 조성된 산악지반에서 진행되었으 며, 측정시간과 강우량에 따라 지반특성의 변화를 도출하였 다. $60 \mathrm{~mm}$ 강우 후 1 시간 뒤에 지반의 상태가 보통에서 느슨함으로 변화하였으며, 시간이 지남에 따라 점점 지반의 강도가 감소하는 것으로 나타났다. $60 \mathrm{~mm}$ 강우조건에서 심도 $300 \mathrm{~mm}$ 까지는 1시간 후의 체적함수비가 3시간 후의 체적함수비보다 높은 것으로 나타났으며, 그 이후 심도에서 는 투수 특성으로 인하여 3시간 후의 체적함수비가 더 크게 산정되었다. 그리고 강우량이 증가할수록 3 시간 후에 측정 된 지반의 강도는 점점 감소하였으며, 강우량 $60 \mathrm{~mm}$ 를 기준으로 지반의 강도가 급격하게 느슨해졌다. 체적함수비 또한 강우량 $60 \mathrm{~mm}$ 를 기준으로 체적함수비가 크게 증가하 는 것으로 나타났다.

본 논문은 국내 산악지반 특성을 파악하고자 하였으며, 실내실험과 현장실험을 통해 국내에 적합한 공학정수를 도출하고자 하였다. 하지만 현장특성상 같은 구역에서도 서로 다른 지반특성을 보일 수 있으며, 이에 따라 강우조건에 대해 도출된 결과의 신뢰성이 다소 떨어질 수 있다. 추후 연구를 통해 일정한 특성을 나타내는 지반을 조성한 후 강우조건을 달리하여 지반특성을 평가하고자 한다.

실내실험과 현장실험 결과를 통해 다음과 같은 결론을 내릴 수 있다.

(1) $60 \mathrm{~mm}$ 강우 후 측정시간에 따라 DCPI는 증가하는 경향이 나타나며, 체적함수비의 경우 침투현상으로 심도 $300 \mathrm{~mm}$ 까지는 1시간 후의 체적함수비가 3시간 후의 체적함수비보다 높게 나타났지만, 그 이후 심도 에서는 반대의 경향을 나타냈다.

(2) 강우량이 클수록 DCPI와 체적함수비는 증가하며, 강우량 $60 \mathrm{~mm}$ 를 기준으로 지반의 강도가 급격히 감소하였으며, 체적함수비는 급격히 증가하는 것으 로 나타났다,

(3) 강우 전, 3 시간 강우량 $30 \mathrm{~mm}, 60 \mathrm{~mm}, 90 \mathrm{~mm}$ 의 지반강도와 체적함수비를 비교하면, 국내 호의주의보 기준인 강우강도 $60 \mathrm{~mm} / 3 \mathrm{hr}$ 를 기점으로 지반강도는 급격히 감소하며, 체적함수비는 급격히 증가하는 것으 로 보인다.

\section{감사의 글}

본 연구는 국토교통부/국토교통과학기술진흥원의 스마 트시티 혁신성장동력 프로젝트 지원(과제번호 R1824541) 으로 수행되었으며 이에 감사드립니다.

\section{References}

Abu-Farsakh, M.Y., Alshibli, K., Nazzal, M., and Seyman, E. (2004). Assessment of in-situ test technology for construction control of base courses and embankments. No. FHWA/LA. 04/389, Louisiana Transportation Research Center.

Byun, Y.H., and Lee, J.S. (2013). Instrumented dynamic cone penetrometer corrected with transferred energy into a cone tip: A laboratory study. Geotechnical Testing Journal, Vol. 36, No. 4, pp. 533-542.

Byun, Y.H., Yoon, H.K., Kim, Y.S., Hong, S.S., and Lee, J.S. (2014). Active layer characterization by instrumented dynamic cone penetrometer in Ny-Alesund, Svalbard. Cold Regions Science and Technology, Vol. 104-105, pp. 45-53.

De Mello, V.F. (1971). The standard penetration test: A state of the art report. Proceedings of the fourth Pan-American conference on soil mechanics and foundation engineering, San Juan, Puerto rico, pp. $1-86$

Hong, W.T., Jung, Y.S., Lee, J.S., and Byun, Y.H. (2015). Development and application of TDR penetrometer for evaluation of soil water content of subsoil. Journal of the Korean Geotechnical Society, Vol. 31, No. 2, pp. 39-46.

Jeong, S.S., Hong, M.H., and Kim, J.H. (2018). A wireless sensor network technique and its application in regional landslide monitoring. Journal of the Korean Geotechnical Society, Vol. 34, No. 9, pp. 19-32.

Kim, J., Jeong, S., and Regueiro, R.A. (2012). Instability of partially saturated soil slopes due to alteration of rainfall pattern. Engineering Geology, Vol. 147-148, pp. 28-36.

Kim, J.H., Jeong, S.S., Kim, Y.M., and Lee, K.W. (2013). Proposal of design method for landslides considering antecedent rainfall and in-situ matric suction. Journal of the Korean Geotechnical Society, Vol. 29, No. 12, pp. 11-24.

Kim, S., Lee, J.S., Hong, S., and Byun, Y.H. (2016). Study on correlation between dynamic cone resistance and 
shear strength for frozen sand-silt mixtures under low confining stress. Journal of the Korean Geoenvironmental Society, Vol. 17, No. 1, pp. 5-12.

Kim, S.Y., and Lee, J.S. (2019). Energy correction of dynamic cone penetration index for reliable evaluation of shear strength in frozen sand-silt mixtures. Acta Geotechnica, pp. 1-15. doi:10.1007/s11440-019-00812-y

Kim, S.Y., Hong, W.T., and Lee, J.S. (2019). Role of the coefficient of uniformity on the California bearing ratio, penetration resistance, and small strain stiffness of coarse arctic soils. Cold Regions Science and Technology, Vol. 160, pp. 230-241.

Lee, J.S., Song, C.G., Kim, H.T., and Lee, S.O. (2015). Risk analysis considering the topography characteristics of debris flow occurrence area. J. Korean Soc. Hazard Mitig., Vol. 15, No. 3, pp. 75-82.

Lee, J.S., Hong, W.T., Park, K., Hong, S.S., Lee, S.H., and Byun, Y.H. (2018). Evaluation of water content in an active layer using penetration-type time domain reflectometry. Applied Sciences, Vol. 8, No. 6, Article No. 935. doi:10.3390/app8060935

Meyerhof, G.G. (1961). Compaction of sands and bearing capacity of piles. Transactions of the American Society of Civil Engineers, Vol. 126, No. 1, pp. 1292-1322.

Mohammadi, S.D., Nikoudel, M.R., Rahimi, H., and Khamehchiyan, M. (2008). Application of the dynamic cone penetrometer (DCP) for determination of the engineering parameters of sandy soils. Engineering Geology, Vol. 101, No. 3-4, pp. 195-203.

O'Connor, K.M., and Dowding, C.H. (1999). Geomeasurements by pulsing TDR cables and probes. Boca Raton, FL: CRC Press.

Rahim, A., Prasad, S.N., and George, K.P. (2004). Dynamic cone penetration resistance of soils: Theory and evaluation. In M.K. Yegian, and E. Kavazanjian (Eds.), Geotechnical engineering for transportation projects (pp. 1755-1766). Reston, VA: American Society of Civil Engineers.

Sawangsuriya, A., and Edil, T. (2005). Investigation of DCP and SSG as alternative methods to determine subgrade stability. Wisconsin Highway Research Program.

Shin, H. (2014). FEM numerical formulation for debris flow. Journal of the Korean Geotechnical Society, Vol. 30, No. 10, pp. 55-65.

Shin, H. (2015). Evaluation of debris properties using numerical analysis for USGS debris flume tests. $J$. Korean Soc. Hazard Mitig., Vol. 15, No. 3, pp. 215-221.

Sun, Y., Cheng, Q., Lin, J., Lammers, P.S., Berg, A., Meng, F., et al. (2011). Energy-based comparison between a dynamic cone penetrometer and a motor-operated static cone penetrometer. Soil and Tillage Research, Vol. 115-116, pp. 105-109.

Topp, G.C., Davis, J.L., and Annan, A.P. (1980). Electromagnetic determination of soil water content: Measurements in coaxial transmission lines. Water Resources Research, Vol. 16, No. 3, pp. 574-582.

Yune, C.Y., Jun, K.J., Kim, K.S., Kim, G.H., and Lee, S.W. (2010). Analysis of slope hazard-triggering rainfall characteristics in Gangwon Province by database construction. Journal of the Korean Geotechnical Society, Vol. 26, No. 10, pp. 27-38.

\begin{tabular}{l|l} 
Received & July 31, 2019 \\
\hline Revised & August 2, 2019 \\
Accepted & August 14, 2019
\end{tabular}

